\title{
The Creation of the FT-NIR Calibration for the Determination of the Amount of Corn Grain in Concentrated Feed
}

\author{
Mutlu Yildirim \\ Vet. Surgeon, Yalvac, Isparta, Turkey \\ E-mail: veterineryildirim@hotmail.com \\ Ismail Bayram (Corresponding author) \\ Faculty of Veterinary, Afyon Kocatepe University \\ ANS Campus 03100, Afyonkarahisar, Turkey \\ E-mail: ibayram1965@gmail.com
}

\author{
The research is financed by BAPK of Afyon Kocatepe University. Project number: 16 SAGBIL.17. The \\ autors thank to $A K U-B A P K$.
}

\begin{abstract}
This study was carried out to determine the proportion of corn grain used in laying hen concantrate feeds quantitatively by means of near infrared spectroscopy (NIR) device. For this purpose, different laying hen concentrate feed consisting of 60 pieces of $1 \mathrm{~kg}$ mixture was formed by increasing the concentration of $1 \%$ in each ration from $1 \%$ to $60 \%$. Functional NIR spectra of feed mixtures were obtained at wavelengths of $10000-4000 \mathrm{~nm} / \mathrm{cm}$. The spectra were evaluated by using PLS (Partial Least Square) method on the second derivative. In the normalization study, SNV (Standard Normal Variate) method was applied. In addition, data obtained from first order (1st Derivation B Cap 5 Points Gap 2) were prepared for regression. Linear regression was applied to the normalized spectra by subtracting the Outlier values from the calibration set and calibration quality parameters were revealed. At this stage, the standard deviations of the $\mathrm{R}^{2}$ value, validation and calibration set were calculated. According to the reflections, the graphs obtained with Regression Coefficients were taken. In addition, the sum of the squares of the estimation residual error (VSet PRESS) of the validation set was also revealed. Outlier values were determined by the program and were not included in the study due to lowering the calibration quality. In the research, $\mathrm{R}$ value was determined as $0.9985, \mathrm{R}^{2}$ value, 0.9970 and standard error value as 0.9352 . The estimated residual error of the validation set obtained was around 14 with the help of V-Set PRESS (Principal Components). The obtained regression consistency was obtained by dividing the standard error value (SEC) of the calibration to the standard error of estimation (SEP). The consistency value was determined between 80 and 110 . These results suggest that NIR or FT-NIR spectroscopy can be used to predict the extent to which the corn grain is quantitatively introduced in laying hen feed mixtures. As a result, it was concluded that the percentage of each feed raw material entering the concentrate feed mixes can be quantitatively determined using FT-NIR spectroscopy as a fast and practical method.
\end{abstract}

Keywords: Corn grain, laying hen feeds, FT-NIR, quantitative

DOI: $10.7176 / \mathrm{JSTR} / 5-8-08$

\section{Introduction}

The mixed feed is produced in commercial feed mills in Turkey, which are presently used methods with the raw materials forming the feed can not be determined exactly. This makes it difficult to accurately determine the quality of the feed produced. In feed industry developed countries, quality questioning of compound feeds produced according to formulations is rather than questioning which feed raw materials are composed of mixed feeds. Studies are carried out in the form of adulteration product screening in feed raw materials entering the mixtures. This situation is the problem of underdeveloped countries.

NIRS technology is a method of near-infrared reflection upon the absorption of electromagnetic radiation

73 | P a g e

www.iiste.org 
in the wavelength range of $400-2500 \mathrm{~nm}$. The nutritional values of the pre-calibrated raw feed materials are determined and used for the analysis of raw feed materials. The nutrient values of the feedstuffs are then quickly determined. Knowing the values of the raw materials in the feed mix directly affects the accuracy of the feed mix. Today, near-infrared reflection (NIR) devices are becoming widespread, giving rapid results to replace traditional wet chemical analyzes (Cen and He 2007). NIR is mostly used in biological applications related to food and agricultural industries. A minimum amount of sample can be analyzed (eg no pretreatment of the sample is required). They can give information about the physical and chemical properties of feeds. Its popularity is increasing as an analytical technique as it does not require damage or destruction of the test sample and can be easily used (Blanco and Bano, 1998; Tikuisis et al. 1993; Tomas and Bayram, 2019). The NIR spectrum combination bands have absorption ranges from $780 \mathrm{~nm}$ to 2500 $\mathrm{nm}$. In other words, the spectral absorption properties in this region relate to existing organic materials. Therefore, NIR spectroscopy of organic material can be used to analyze various properties according to the absorption intensities of certain wavelengths (Lohumi, 2015). Plenty of studies have been conducted using the NIR method to determine the quality of cereal seeds. In these studies, moisture, protein, fat, starch, amino acids and fatty acids were analyzed quantitatively. In addition, specific properties such as hardness, insect infection, mold, and toxin infection as well as nutrient contents have been studied in various seeds (Agelet and Hurburgh, 2014; Huang et al., 2015). Today, NIR technology is used in large areas such as agriculture, food, pharmaceuticals, and biological systems. In the NIR method, quantitative analysis of spectral data requires a calibration step with a series of standard samples (Blanco and Bano, 1998). NIR technology can also be used to detect amino acids in industrial foods (Gonzalez-Martin et al. 2006).

Corn, also known as Indian corn; (Zea mays), or "maize", is the cereal plant of edible grains of the grass family (Poaceae). Maize is used as a feed for livestock, as human food, as a biofuel and as a raw material in the feed industry (Anonymous, 2019). In one study, FT-NIR method was used to estimate the amount of protein, starch, and fat in corn grain. In the study, starch values showed the lowest correlation values, $\mathrm{R}^{2}=$ 0.86 for calibration and $\mathrm{R}^{2}=0.89$ for validation (Jiang et al., 2007). For the determination of corn starch in the product obtained by the wet grinding process, the calibration value was found to be $\mathrm{R}^{2}=0.8$ (Paulsen et al. 2010). Nutrient contents of DDGS obtained from corn were analyzed by FT-NIR. In this method, $\mathrm{R}^{2}=$ 0.81 for the starch value of DDGS, $\mathrm{R}^{2}=0.88$ for protein and $\mathrm{R}^{2}=0.87$ for moisture (Paulsen et al. 2010). In a study to determine protein, starch and fat content of maize by using of NIR device (Jiang et al. 2017); protein, starch, and fat contents were found to be the same as the results determined by wet chemical method. The researchers concluded that the NIR method can be used to quickly detect protein, starch and fat content. In another study, differences between wheat and corn starch were determined using the NIR method (Hodsagi et al. 2012). The NIR method has introduced a revolutionary approach to the methods of rapidly and accurately analyzing animal feed, and its popularity is increasing day by day. Especially in the field of animal husbandry, the nutrient values of the feeds are determined and it plays a vital role in estimating the values of water, protein, starch, and fat in the ration. This method will often be used as a feed evaluation method in the near future (Givens et al. 1997).

During the production of concentrated feed, many tricks are used to mislead consumers. For this purpose, mixing urea into soybean meal or protein concentrates, adding crab flour into fish meal or mixing blood flour into meat bone meal are some of them. Although the method used in the present study is not the same, it is similar to the quantitative determination method used to determine feed adulterations by NIR method. In a study related to the subject, PLS and PCR analyses were performed as a regression analysis on NIR device in order to estimate adulteration in crab meat. The accuracy of the estimation models was examined in terms of low standard calibration error (SEC), low standard estimation error (SEP) and high correlation coefficient $\left(R^{2}\right)$. In the study, the standard error of calibration was found to be $0.251, R^{2}: 0.997$, estimation standard error: 0.252 , and $\mathrm{R}^{2}$ value was 0.997 . The results show that NIR technology can be used successfully to detect adulteration in crab meat samples prepared with imitation crab meat (Gayo et al. 2006).

This study was carried out to determine the quantitative determination of grain maize in hen rations by means of NIR device.

\section{Material and Method}

The research was carried out with feedstuffs obtained from a commercial feed factory. Corn, wheat, barley, vegetable oil, sunflower meal (23\% and $36 \mathrm{CP}$ ), soybean meal, limestone, salt, vitamin-mineral mix, lysine, and methionine were used as feedstuffs. In this study, 60 commercial laying hens rations with $1 \mathrm{~kg}$ weight, the same nutritional values, isocaloric and isonitrogenic were prepared. The norms of NRC (2005) are based on the regulation of nutrient values of diets. In 60 feed mixtures, $1 \%$ corn was used in the number one ration, then the corn was increased by $1 \%$ in each ration, respectively, up to $60 \%$ in the last ration. Each feedstuff was milled with an ultra-centrifugal rotor grinder (ZM200, Retsch Ltd., Düsseldorf, Germany) and passed

74 I P a g e 
through sieves of $1 \mathrm{~mm}$ diameter. The milled and sieved samples were used to prepare the rations weighing one $\mathrm{kg}$ each, according to the ration formulation. The prepared rations were kept in $1 \mathrm{~kg}$ airtight nylon bags. After preparation, spectra were collected from two separate points of each ration sample. During the spectra collection process, samples taken into glass Petri were placed on the automatic rotor part of the NIR device (NIRMaster ${ }^{\circledR}$, Büchi Labortechnik AG, Flawil, Switzerland) and spectra were collected from each sample three times. Calibration and statistical evaluations based on the obtained spectra data were evaluated with NIRCAL program (Büchi Labortechnik AG, Flawil, Switzerland). Within the spectra itself, calibration and validation sets are separated with the help of the program. The spectra obtained were evaluated by the second derivative and PLS (Partial Least Square) method. SNV (Standard Normal Variate) method was used in the data of normalization study. In addition, the first-order derivative (1st Derivation B Cap 5 Points Gap 2) data was made ready for regression. Outlier values were subtracted from the calibration set and linear regression was applied to normalized spectra and calibration quality parameters were determined. At this stage $\mathrm{R}^{2}$ value, standard deviations of validation and calibration set were calculated. The graphs obtained with the regression coefficients were printed according to the reflectances. In addition, the estimation residual error of the validation set was found in the sum of squares (V-Set PRESS). Outlier values were determined by the program and were not included in the study due to the decrease in calibration quality.

\section{Results}

The reflectance views $(1 / \log )$ and normalized spectra resulting from the preliminary applications applied to the spectra are shown in Figure 1.

\section{Pretreated Spectra}

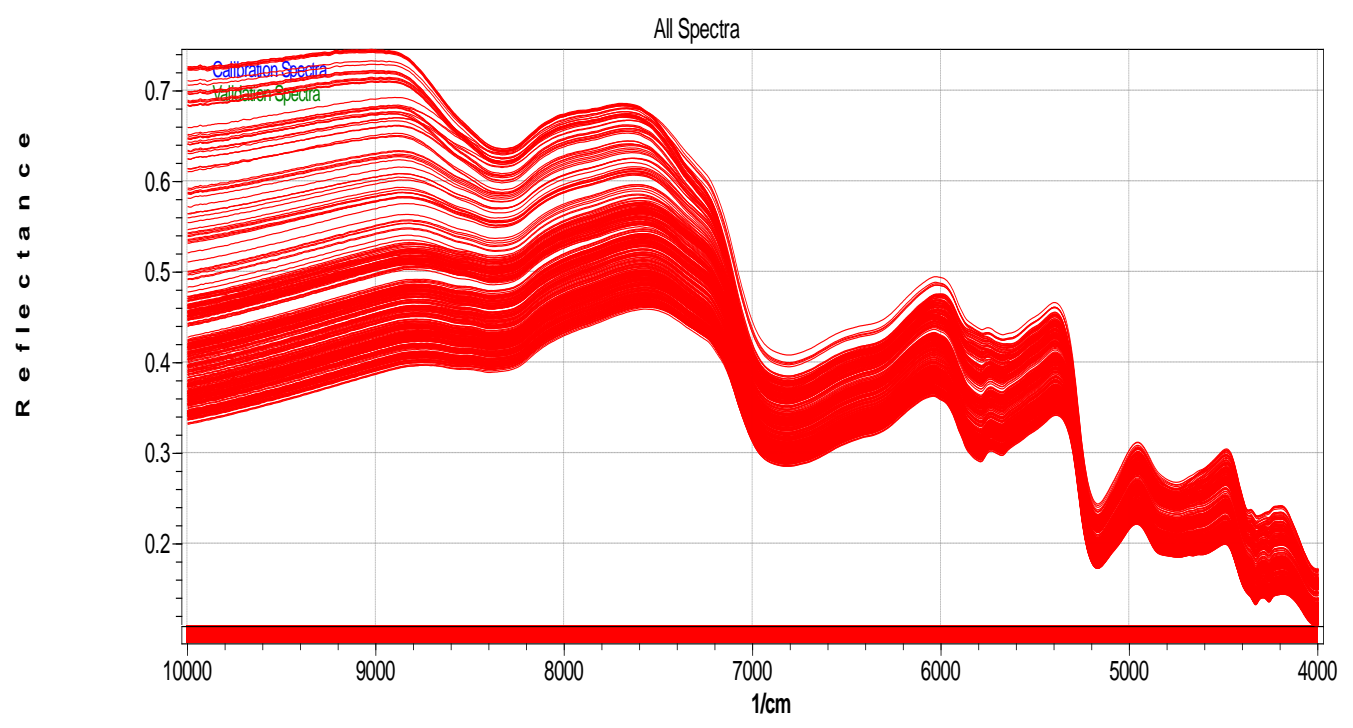

Figure 1. Spectra Set.

Functional spectra obtained after application was determined at wavelengths of $10000-4000 \mathrm{~nm} / \mathrm{cm}$.

The principal component value (Principal Components) of the validation set was estimated as 14 by the squares sum graph (V-Set PRESS) of the estimation residual error. Basic component values via V-Set PRESS are shown in Figure 2. 


\section{V-Set PRESS}

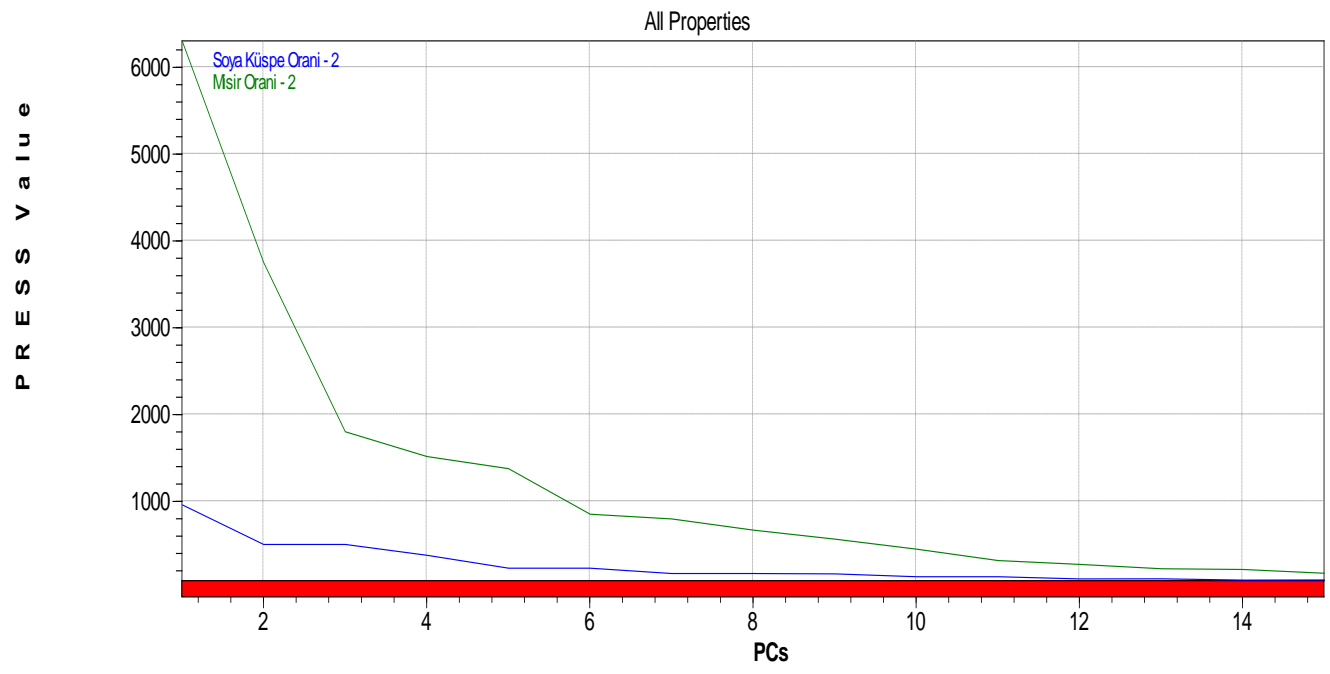

Figure 2. Estimation of Sum of Squares of Residual Error.

The obtained regression consistency was obtained by dividing the standard error value (SEC) of the calibration by the estimation standard error (SEP). Consistency value was determined between 80 and 110 . The results of the consistency analysis are shown in Figure 3.

\section{Consistency}

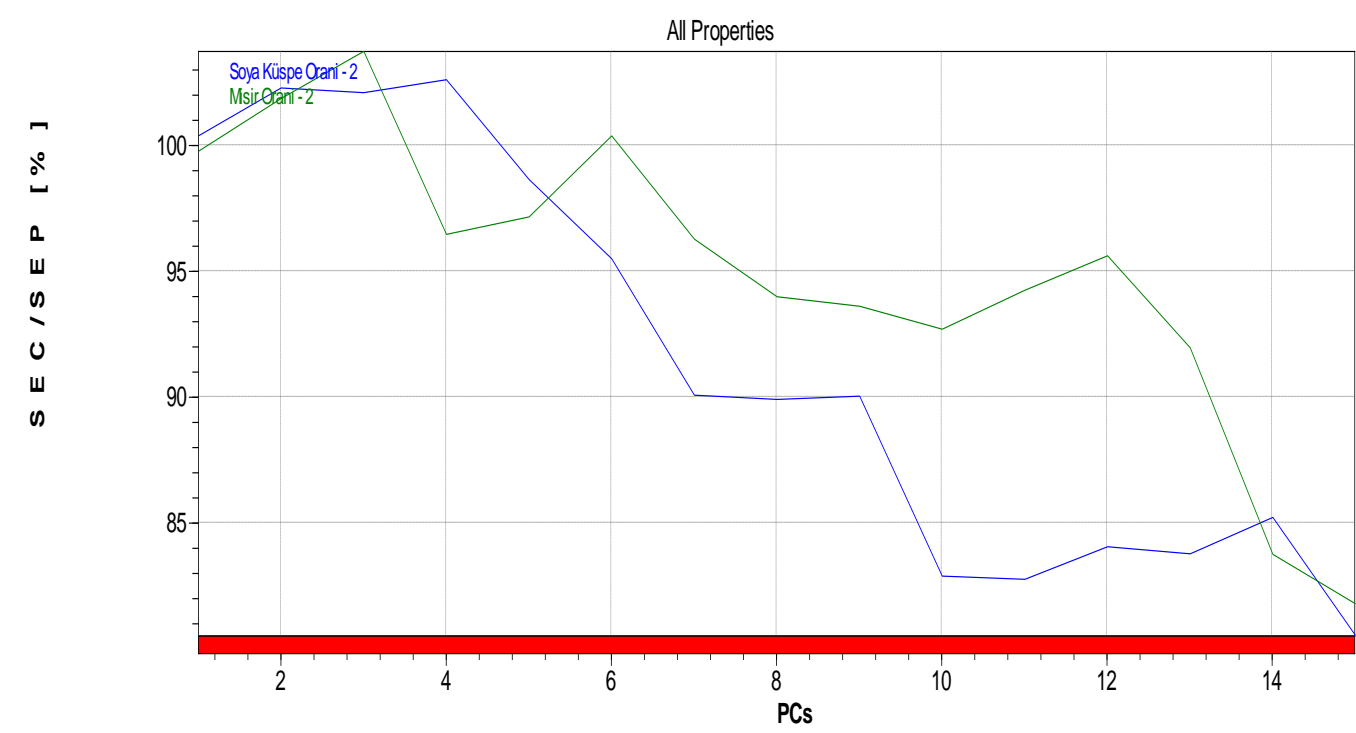

Figure 3. Consistency Analysis of Calibration Set. 
The output of the linear regression values obtained from the calibration and validation sets is shown in Figure 4 .

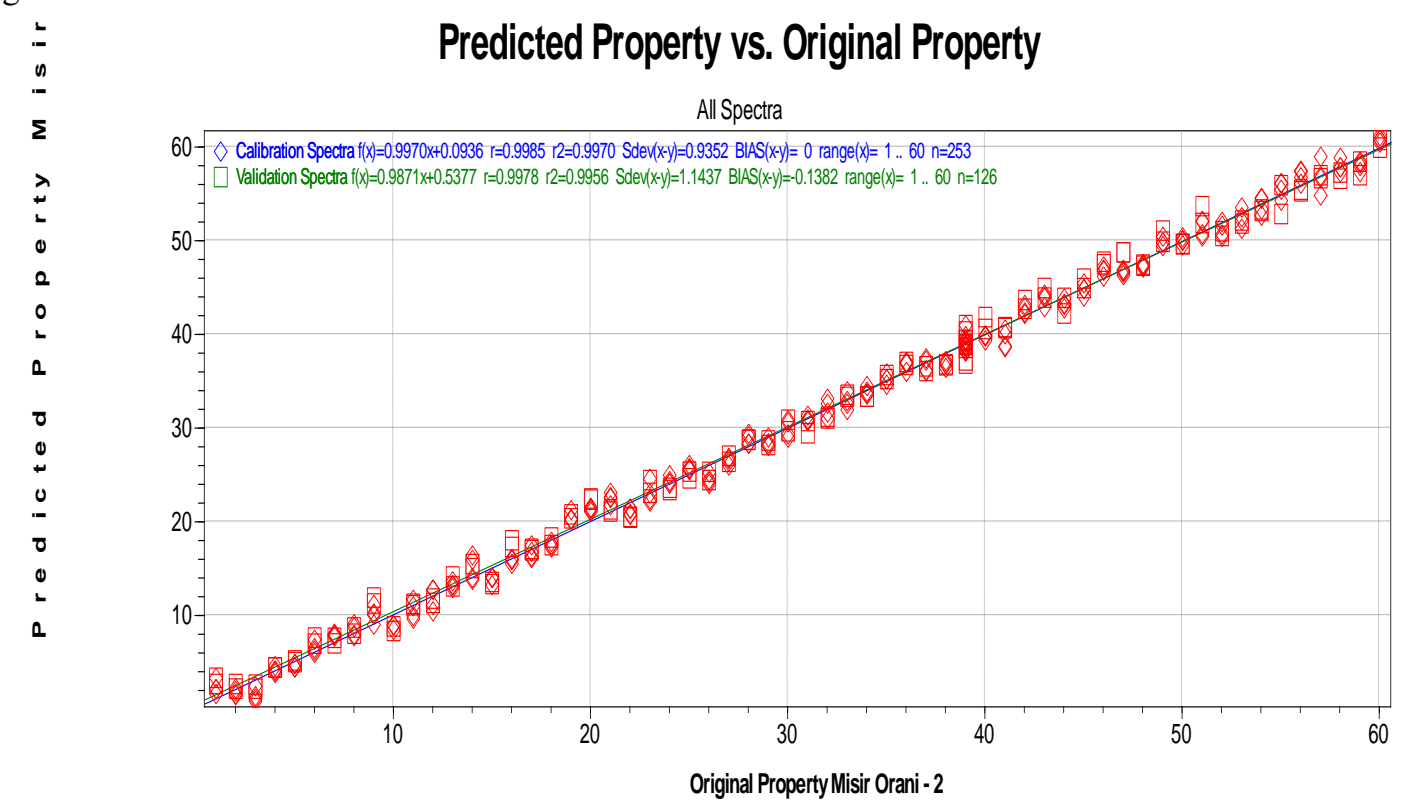

Figure 4. Calibration and Validation Set Models

The regression analysis included 253 measurements in the calibration set and 126 measurements in the validation set. As a result of the analysis, the model of Calibration and Validation sets was formed as follows:

Calibration set:

- $f(x)=0.9970 \mathrm{x}+0.0936$

- $\mathrm{r}=0.9985$

- $r^{2}=0.9970$

- $\quad$ Standart deviation $=0.9352$

- BIAS $=0$

\section{Validation set:}

- $f(x)=0.9871 x+0.5377$

- $\mathrm{r}=0.9978$

- $\mathrm{r}^{2}=0.9856$

- $\quad$ Standart deviaton $=1.1437$

- $\quad$ BIAS $=0.1382$

\section{Discussion}

The subject of this study, the feeding of poultry by corn grain most widely used in Turkey. For this purpose, 60 different rations were prepared for laying hens and corn was used in increasing amounts from $1 \%$ to $60 \%$. It was aimed to determine the amount of corn grain in these prepared rations by means of NIR device. Thus, the amount of corn used in commercial poultry feeds was determined by NIR. In addition, it was tried to indirectly determine the feasibility of determining the exact amounts of not only corn but also other feedstuffs in commercial concantrate feeds. In this study, feedstuffs were obtained from a private feed factory, each feedstuffs were grinded in laboratory and 60 feed mixtures were prepared according to the certain rations in order to form the rations to be taken spectra in NIR device. Starting from $1 \%$ in the feed mixes, the next ration was increased by 1 unit and $1 \%$ to $60 \%$ corn was used. Afterwards, each feed mixture (ration) was read 3 times in NIR device in order to get spectra and 180 spectra were taken in total. $\mathrm{R}^{2}$ (determination coefficient value) value is used to calculate the estimation value in NIR calibration studies. This $\mathrm{R}^{2}$ value is the regression coefficient which is the coefficient of determination of the relationship between the variables; $\mathrm{R}$ value is calculated by taking the square (Sohn et al., 2006). This determined $\mathrm{R}^{2}$ value is between 0 and 1 numbers. The closer this value is to the integer 1 , the more powerful 
it is considered, and in a way it shows that the calibration result is very reliable (Sohn et al., 2006). In the research, $\mathrm{R}$ value, $0.9985, \mathrm{R}^{2}$ value, 0.9970 and standard error value were determined as 0.9352 as spectra set. No similar NIR calibration studies were conducted to determine the amount of feedstuffs added to the feed in mixed feeds. This may be due to the fact that feed producers and dietary formula makers rely on ration formulations, the engineering level of the mixing machines is extremely high, in other words, feeders rely on their feed mix and technical equipment. The problem here is that in underdeveloped countries, feed mills misrepresent the raw materials they produce and then add to the feed they use by using gaps in the law, and this cannot be detected by the official controllers. Although not the same type of studies, there are logically similar quantitative studies to detect adulteration tricks in feedstuffs or food for human consumption. From $0 \%$ to $30 \%$ of meat $(0 \%, 1 \%, 2 \%, 3 \%, 4 \%, 5 \%, 6 \%, 7 \%, 8 \%, 9 \%, 10 \%, 15 \%, 20 \%, 25 \%$ and $30 \%$ ) Rcv2 (cross validation) value was determined in the range of 0.99-0.98 in adulteration study by adding 4 different soy flour (Jiang et al. 2017). As a result, it was demonstrated by using the FT-NIR method that the soy products added to meat products such as sausage, salami and sausage can be quantitatively determined. In a similar FT-NIR study, sesame oil; hazelnut, canola and sunflower oils were mixed with $1 \%, 2 \%, 4 \%, 5 \%, 10 \%, 15 \%, 20 \%, 25 \%, 30 \%, 35 \%, 40 \%, 45 \%, 50 \%$. In the study, $\mathrm{R}^{2}$ values for hazelnut oil; 0.9633 for canola oil; 0.9344 and 0.9618 for the sunflower oil. As a result of this study, it was concluded that the determination of different oils added to sesame oil by FT-NIR method can be done in a short time, without destroying the structure of the oils and without the use of any chemical substances (Ozulku ve ark.2017). This result and method confirm the accuracy of the method and the path taken in the present study. In another adulteration study, different types and sugars were added to the honey. In the study, sugar and honey were mixed in different ratios from $0 \%$ to $100 \%$. In conclusion, in this study, it was shown that sugar adulteration can be detected quickly and easily by NIR spectroscopy method. In the same study, functional spectra were obtained at a wavelength of $8000-4000 \mathrm{~nm} / \mathrm{cm}$. This result is similar to the functional spectra of 10000-4000 $\mathrm{nm} / \mathrm{cm}$ wavelengths obtained in the present study.

The obtained regression consistency was obtained by dividing the standard error value (SEC) of the calibration by the estimation standard error (SEP). Consistency value was determined between 80 and 110 . In a similar study, in order to determine the estimation capacity of the regression method, external validation was performed by using honey samples prepared with $5 \%, 15 \%, 25 \%$, and $45 \%$ samples and adulteration product addition sample set. A pure honey sample was also included in the prediction study (GonzalezMartin et al. 2018). These results show the accuracy of the developed model. In the study, the error was found to be less than $1 \%$ for all honey samples adulterated below $45 \%$. The actual and estimated values of the adulteration study performed on the honey sample using PLS method are as follows; $0.69 \%$ for $0 \%$, $.5 .27 \%$ for $5 \%, 14.85 \%$ for $15 \%, 24.31 \%$ for $25 \%$ and $42.63 \%$ for $45 \%$. In another study related to the subject (Cuibus et al., 2014), calibration was developed by using FT-NIR and PLS method in cheeses adulterated with solid palm oil in different ratios. In the study, mean recovery rate was found to be 108 and $\mathrm{R}^{2}$ value was found to be 0.9695 . The actual and predictive values of adulteration in cheese samples using PLS were found to be $4.0 \%$ for $5 \%, .10 .1 \%$ for $10 \%, 20.2 \%$ for $15 \%, 24.2 \%$ for $20 \%$ and $41.6 \%$ for $40 \%$, respectively. The regression consistency value obtained in the present study varies between $80-110$ and confirms the high accuracy of the results.

\section{Conlusion}

This study is a preliminary investigation of the use of FT-NIR spectroscopy to estimate the amount of grain maize added to commercial concentrate feeds in different ratios. High validation $\mathrm{R}^{2}: 0.9856$ showed that the NIR spectroscopy method could detect the amount of maize in laying hens concentrate feeds. The amount of corn in concentrated feed was shown to be $99 \%$ accuracy by the NIR method. In addition, a high correlation coefficient was obtained in PLS regression analysis. However, grain maize in the range of $1 \%$ to $60 \%$ in the mixed feed can be detected with high accuracy by NIR spectroscopy. This suggests that it is possible to establish NIR calibration to estimate the corn level in the concentrate feed mixture. As a result, it was concluded that the reliability could be increased by adding and increasing the corn concentrations in the range of $0.5 \%$ instead of $1 \%$ in order to determine the corn amount in full.

\section{References}

Agelet, L.E.; Hurburgh, C.R. (2014). Tek tohum analizi için kızılötesine yakın izgeölçümün güncel uygulamaları ve kisitlamaları. Talanta, 121, 288-299.

Anonim (2019a). https://en.wikipedia.org/wiki/Maize Erişim tarihi: 22.05.2019

Blanco, M., Bañó,R.G. (2003). Kızılötesi izgeölçümüyle nişasta hidrolizatlarındaki şekerlerin saptanmasi. Analytical Letters36: 1607-1619.

78 I P a g e

www.iiste.org 
Cen H, He Y. (2007). Besin kalitesinin saptanmasında kızılötesine yakın yansıtma izge ölçümün uygulamas1 ve teorisi.Trends in Food Science \& Technology.; 18(2): 72-83.

Cuibus,L. Maggio,R., Mureșan,V., Diaconeasa,Z., Fetea,F., Socaciu,C. (2014). Preliminary Discrimination of Cheese Adulteration by FT-IR Spectroscopy Bulletin UASVM Food Science and Technology 71(2).

Gayo,J., Hale,S.A., Blanchard,S.M. (2006). Quantitative Analysis and Detection of Adulteration in Crab Meat Using Visible and Near-Infrared Spectroscopy. J. Agric. Food Chem. 54, 1130-1136.

Givens DI, De Boever JI, Deaville ER.(1997). Hayvanlar ve insanlar için gıdaların besin değerlerinin tahmini için kızı̈ötesine yakın izgeölçümün prensipleri, yöntemleri ve gelecekte bazı uygulamalar1.Nutr. Res. Rev., 10(1): 83-114.

González-Martin I, Hernández-Hierro JM, Bustamante-Rangel M, Barros-Ferreiro N. (2006). Şark yoncasındaki tokoferolların saptanması için kızılötesine yakın izgeölçümü (NIRS) yansıtma teknolojisi..Analytical and Bioanalytical Chemistry. 2006; 386: 1553-1158.

Hódsági M, Gergely S, Gelencsér T, Salgó A. (2012).Kızılötesine yakın izgeölçümü kullanarak yerel ve dirençli nişastaların ve karışımlarının araştırmaları. Food and Bioproc. Tech., 5(1):401-417.

Huang, M.;Wang, Q.G.; Zhu, Q.B.; Qin, J.W.; Huang, G. (2015). Optik hissetme teknolojileri kullanarak tohum kalitesi ve güvenliği testlerinin incelenmesi. Seed Sci. Technol., 43, 337-366.

mısır çekirdeklerinin analizinin elverişliliği. J. Cereal Sci., 69, 145-150.

Jiang,H.,Zhuang,H., Sohn,M., Wang,W.(2017). Measurement of Soy Contents in Ground Beef Using Near-Infrared Spectroscopy Appl. Sci. 7, 97;

Lohumi, S.; Lee, S.; Lee, H.; Cho, B.K.(2015). Gıda otantikliğini ve olgunlaşmasını saptamak için kullanılan titreşimsel izgeölçüm yöntemlerinin bir incelemesi. Trends Food Sci. Technol., 46, 85-98.

Paulsen, M.R., Rathore, S.S.S., Steffen, R.W., Zhang, Y., Wrenn, B., Schlicher, M., Kennay. A.L. (2010). DDGS'nin kimyasal özelliklerinin izgeölçüsel saptanması. Paper No. 1009113. American Society of Agricultural and Biological Engineers Annual International Meeting, Pittsburgh, PA

Sohn, M., Himmelsbach, D.S., Morrison, W.H., Akin, D.E., Barton, F.E. (2006).Partial Least Squares Regression Calibration for Determining Wax Content in Processed Flax Fiber by Near-Infrared Spectroscopy. Society for Applied Spectroscopy.; 60: 437-440.

Tikuisis, T., Axelson, D.E., Sharma, A. (1993). Katı hâldeki NMR ve FTIR ile polietilendeki nişasta içeriğinin yıkımsız nicel saptaması. Polymer Engineering \& Science33: 26-31

Tomas,E., Bayram,I. (2019). Establishing Near Infra Red Spectroscopy (NIR) Calibration for Starch Analysis in Corn Grain. Kocatepe Vet.J.12(1),7-14.

Lawrence, S. et al. (2001). Persistence of Web References in Scientific Research. Computer. 34, 26-31. doi:10.1109/2.901164, http://dx.doi.org/10.1109/2.901164.

Smith, Joe, (1999), One of Volvo's core values. [Online] Available: http://www.volvo.com/environment/index.htm (July 7, 1999)

Strunk, W., Jr., \& White, E. B. (1979). The elements of style. (3rd ed.). New York: Macmillan, (Chapter 4).

Van der Geer, J., Hanraads, J. A. J., \& Lupton R. A. (2000). The art of writing a scientific article. Journal of Scientific Communications, 163, 51-59 